\title{
Causes of death in patients with asthma and asthma-chronic obstructive pulmonary disease overlap syndrome
}

This article was published in the following Dove Press journal:

International Journal of COPD

18 March 2015

Number of times this article has been viewed

\section{Tomoya Harada \\ Akira Yamasaki \\ Takehito Fukushima \\ Kiyoshi Hashimoto \\ Miki Takata \\ Masahiro Kodani \\ Ryota Okazaki \\ Kenichi Takeda \\ Masanari Watanabe \\ Jun Kurai \\ Eiji Shimizu}

Division of Medical Oncology and Molecular Respirology, Department of Multidisciplinary Internal Medicine, Tottori University, Yonago, Japan
Correspondence: Akira Yamasaki Division of Medical Oncology and Molecular Respirology, Department of Multidisciplinary Internal Medicine, Tottori University, 36-I Nishi-cho,

Yonago, Tottori, Japan

$\mathrm{Tel}+8 \mathrm{I} 859386537$

Fax +8I 859386539

Email yamasaki@grape.med.tottori-u.ac.jp
Background: The administration of inhaled corticosteroids and worldwide usage of several asthma guidelines have improved asthma mortality. Elderly patients with asthma show high mortality rates, and may have several comorbidities, including overlap with chronic obstructive pulmonary disease (COPD). Among patients showing asthma overlapped with COPD (asthma-COPD overlap syndrome; ACOS), mortality is worse than for asthma alone. Therefore, we investigated comorbidities, malignancies, and causes of death in patients with asthma and ACOS.

Methods: This was a retrospective study. From January 2000 to March 2012, 650 patients were followed up at Tottori University Hospital. Medical records were reviewed to collect data regarding patient characteristics and comorbidities, and causes of death were recorded for patients who died during the study period.

Results: Eighty-seven patients died during the study period. The most frequent cause of death was malignancy. The proportion of malignant disease was $21.7 \%$ in all patients, $19.4 \%$ in patients with asthma alone, and $32.4 \%$ in patients with ACOS. One patient died from an asthma attack during this period.

Conclusion: The most frequent cause of death in patients with asthma and ACOS was malignant disease. It is necessary to control not only asthma but also comorbidities in patients with asthma, especially in those with ACOS.

Keywords: asthma, chronic obstructive pulmonary disease, asthma-COPD overlap syndrome, mortality

\section{Introduction}

Asthma is a common disease, and its prevalence is increasing worldwide. ${ }^{1}$ The estimated prevalence was 7.9\% among Japanese men and 7.55\% among Japanese women. ${ }^{2}$ Preventing death from an asthma attack is the main goal when treating patients with asthma. ${ }^{3}$ The widespread use of inhaled corticosteroids over the past three decades has decreased asthma mortality. ${ }^{4}$ In 2012, 1,874 patients died of an asthma attack, while over 7,000 patients died every year in the 1970s when inhaled corticosteroids were not a standard asthma medication in Japan. ${ }^{5,6}$ Since elderly adults have shown a high mortality rate, the prevention of asthma deaths in elderly patients is a major component in decreasing the total number of asthma deaths..$^{7-9}$ However, elderly asthma patients may die of other causes besides an asthma attack.

Chronic obstructive pulmonary disease (COPD) is one of the diseases that must be distinguished from asthma, and the two diseases sometimes overlap. COPD was the third leading cause of death worldwide in $2010 .{ }^{10}$ Causes of death in patients with COPD have been investigated in several studies. ${ }^{11-14}$ The most frequent causes 
of death were malignancies, acute respiratory failure, and cardiovascular diseases. ${ }^{11}$ Further, emphysema was reported as an independent risk factor for lung cancer apart from smoking history. ${ }^{15}$

Patients with both asthma and COPD have high mortality rates, ${ }^{16}$ frequent exacerbations, ${ }^{17}$ and poor quality of life ${ }^{18}$ compared with those with asthma or COPD alone. Patients who have features of both asthma and COPD are defined as having asthma-COPD overlap syndrome (ACOS). ${ }^{19}$ However, causes of death in ACOS patients have not been well studied.

In this study, we surveyed malignant disease as a comorbidity and investigated causes of death in patients with asthma and ACOS. We also surveyed the histology of lung cancers in these patients.

\section{Patients and methods}

\section{Patients and data collection}

This study was retrospective in design. Patients who visited Tottori University Hospital and had been treated for asthma from January 2000 to March 2012 were surveyed. During the study period, 2,214 patients were treated for asthma, and 650 patients were diagnosed with asthma according to American Thoracic Society criteria ${ }^{20}$ and followed through to the end of March 2012. Medical records were reviewed to collect data on age, sex, smoking status, comorbidities, past history, whether the patient was alive or dead at the end of March 2012, and the cause of death (if applicable). The study was approved by the institutional ethics board of Tottori University.

\section{Measurement of pulmonary function}

Pulmonary function tests were performed using a Chestac 33 spirometer (Chest Co, Tokyo, Japan). The highest forced vital capacity (FVC) and forced expiratory volume in one second $\left(\mathrm{FEV}_{1}\right)$ values from a minimum of three pulmonary function tests were recorded.

\section{Diagnosis of ACOS}

A clinical diagnosis of ACOS was made based on the guidelines published by GINA (Global Strategy for Asthma Management and Prevention). ${ }^{19}$ Briefly, an ACOS diagnosis was made in cases with a previous diagnosis of asthma, a smoking history of at least 10 pack-years, persistent airflow limitation (a post-bronchodilator $\mathrm{FEV}_{1}$ to $\mathrm{FVC}$ ratio $<0.7$ ), and respiratory symptoms, such as dyspnea on effort, cough, and sputum.

\section{Severity of airflow limitation}

Because classifications of airflow limitation severity differ between asthma and COPD, ${ }^{20}$ we classified patients with asthma and ACOS according to GOLD (Global Initiative for Chronic Obstructive Lung Diseases) criteria, as follows: ${ }^{21}$ stage I, mild airflow limitation ( $\mathrm{FEV}_{1} \geq 80 \%$ predicted); stage II, moderate airflow limitation $\left(50 \% \leq \mathrm{FEV}_{1}<90 \%\right.$ predicted); stage III, severe airflow limitation $\left(30 \% \leq \mathrm{FEV}_{1}\right.$ $<50 \%$ predicted); and stage IV, very severe airflow limitation $\left(\mathrm{FEV}_{1}<30 \%\right.$ predicted). Because no patient with asthma showed very severe airflow limitation, we combined stage III and stage IV patients, and compared causes of death according to severity of airflow limitation, asthma, and ACOS.

\section{Statistical analysis}

All data are expressed as the mean \pm standard deviation. The Mann-Whitney $U$-test and the chi-squared test were used to analyze the two groups. Graph Pad Prism 4.0 software (GraphPad Software Inc, San Diego, CA, USA) was used to perform all statistical analyses. Differences were considered to be statistically significant at $P<0.05$.

\section{Results}

\section{Patient characteristics}

A total of 650 patients were analyzed. The average age, sex, smoking status, and number of patients with ACOS are shown in Table 1. Among the total group of patients, $176(27.1 \%)$ presented ACOS. Eighty-seven patients died during the survey period. The average age, percentage of males, percentage of current or ex-smokers, and percentage of ACOS diagnoses were significantly higher among patients who died $(P<0.01$, Table 1$)$.

\section{Comparison of characteristic features of patients with asthma and ACOS}

We compared the characteristic features of patients with asthma and ACOS (Table 2). Patients with ACOS were significantly older $(P<0.01)$, more likely to be male $(P<0.01)$, had high percentages of current and past smoking histories $(P<0.01)$, low $\mathrm{FEV}_{1} / \mathrm{FVC} \%$ values $(P<0.01)$, and low $\mathrm{FEV}_{1} \%$ predicted values $(P<0.01)$. The average immunoglobulin E level was higher in ACOS patients, but the difference was not statistically significant. The percentage of patients with malignant disease was significantly higher among ACOS patients $(P<0.01)$; the percentage of patients who died among all patients was higher in patients with ACOS than those with asthma ( $P=0.0192$, Table 2$)$. 
Table I Characteristics of the patients

\begin{tabular}{|c|c|c|c|c|}
\hline & All & Living & Deceased & $P$-value \\
\hline Number of patients, n (\%) & 650 & $563(86.6 \%)$ & 87 (I3.4\%) & \\
\hline Age, years, mean $\pm S D$ & $64.4 \pm 16.4$ & $62.8 \pm 16.4$ & $74.5 \pm 11.5$ & $<0.0001$ \\
\hline \multicolumn{5}{|l|}{ Sex, n (\%) } \\
\hline Male & $328(50.5 \%)$ & $265(47.1 \%)$ & $63(72.4 \%)$ & \multirow[t]{2}{*}{$<0.000$ I } \\
\hline Female & 322 (49.5\%) & 298 (52.9\%) & $24(27.6 \%)$ & \\
\hline \multicolumn{5}{|l|}{ Smoking status, n (\%) } \\
\hline Current smoker & $66(10.2 \%)$ & $57(10.1 \%)$ & $9(10.3 \%)$ & \multirow{3}{*}{0.0203} \\
\hline Ex-smoker & $259(39.8 \%)$ & $213(37.8 \%)$ & $46(52.9 \%)$ & \\
\hline Non-smoker & $325(50.0 \%)$ & $293(52.1 \%)$ & $32(36.8 \%)$ & \\
\hline ACOS, n (\%) & $176(27.1 \%)$ & 143 (25.4\%) & $33(37.9 \%)$ & 0.0192 \\
\hline
\end{tabular}

Abbreviations: ACOS, asthma-COPD overlap syndrome; COPD, chronic obstructive pulmonary disease; SD, standard deviation.

\section{Causes of death in all patients}

Among the 87 patients who died, 49 (56.3\%) died of malignant disease. Among patients with malignancy, the percentage who died from lung cancer was highest (13 cases, 14.9\%), hepatobiliary cancer was second highest (12 cases, $13.8 \%$ ), and gastrointestinal cancer was third highest (eight cases, 9.2\%). In addition, 15 patients died of pneumonia, ten of cardiovascular disease, and eight died a sudden death (two of whom died in a bathroom). One patient died of an asthma attack (Table 3).

\section{Causes of death in 87 patients according to diagnosis of asthma or ACOS}

We then compared the causes of death between patients with asthma and those with ACOS. The proportion with malignant disease was $57.4 \%$ in patients with asthma and $54.5 \%$ in patients with ACOS. Among the malignant diseases, lung cancer and hepatobiliary cancer were the highest and second highest causes of death in asthma patients, while gastrointestinal cancer and urological cancer were the most frequent causes of death in ACOS patients. In both groups, the percentage of pneumonia-related deaths was the highest among deaths caused by benign disease. The second highest cause of death among the benign diseases was cardiovascular disease in patients with asthma and sudden death of unknown cause in patients with ACOS (Table 4).

\section{Causes of death in 54 asthma patients classified by degree of airflow limitation}

We analyzed the causes of death in 54 asthma patients classified by airflow limitation. In the group with mild or moderate airflow limitation $\left(\mathrm{FEV}_{1} \%\right.$ predicted $\geq 50 \%$ ), the number of patients with malignant disease was high. In the group with severe airflow limitation $\left(\mathrm{FEV}_{1} \%\right.$ predicted $\left.<50 \%\right)$, the numbers of patients with malignant disease and pneumonia were equivalent (Figure 1A).

\section{Causes of death of 33 ACOS patients classified by degree of airflow limitation}

We next analyzed the causes of death in 33 ACOS patients classified by airflow limitation. In the group with mild or

Table 2 Comparisons of characteristic features of patients with asthma and ACOS

\begin{tabular}{|c|c|c|c|c|}
\hline & All & Asthma & ACOS & $P$-value \\
\hline & $(n=650)$ & $(n=474)$ & $(n=176)$ & \\
\hline Age, years, mean $\pm S D$ & $64.4 \pm 16.4$ & $61.7 \pm 17.1$ & $71.6 \pm 11.0$ & $<0.000$ I \\
\hline \multicolumn{5}{|l|}{ Sex, n (\%) } \\
\hline Male & $328(50.5 \%)$ & $169(35.7 \%)$ & 159 (90.3\%) & $<0.000$ I \\
\hline Female & 322 (49.5\%) & 305 (64.3\%) & 17 (9.7\%) & \\
\hline \multicolumn{5}{|l|}{ Smoking status, n (\%) } \\
\hline Current/ex-smoker & $324(49.8 \%)$ & | 48 (31.2\%) & $176(100.0 \%)$ & $<0.0001$ \\
\hline Non-smoker & $326(50.2 \%)$ & $326(68.8 \%)$ & $0(0.0 \%)$ & \\
\hline $\mathrm{FEV}_{1} / \mathrm{FVC}, \%$, mean $\pm \mathrm{SD}$ & $69.1 \pm 13.7$ & $74.0 \pm 10.9$ & $55.9 \pm 11.6$ & $<0.000$ I \\
\hline$\% F E V$, predicted, $\%$, mean \pm SD & $89.1 \pm 26.2$ & $93.4 \pm 24.7$ & $77.9 \pm 26.8$ & $<0.000$ I \\
\hline $\lg E, I U / L$, mean $\pm S D$ & $532.6 \pm 1,576.3$ & $469.3 \pm 1,557.2$ & $711.1 \pm 1,620.9$ & 0.0870 \\
\hline Malignancies, n (\%) & 149 (22.9\%) & $92(19.4 \%)$ & 57 (32.4\%) & 0.0017 \\
\hline Living, n (\%) & $563(86.6 \%)$ & $420(88.6 \%)$ & $143(81.3 \%)$ & 0.0192 \\
\hline Deceased, n (\%) & $87(13.4 \%)$ & $54(11.4 \%)$ & $33(18.7 \%)$ & \\
\hline
\end{tabular}

Abbreviations: ACOS, asthma-COPD overlap syndrome; COPD, chronic obstructive pulmonary disease; FEV ${ }_{\text {, }}$ forced expiratory volume in one second; FVC, forced vital capacity; IgE, immunoglobulin E; SD, standard deviation; IU/L, international unit per liter. 
Table 3 Causes of death of the deceased subjects

\begin{tabular}{|c|c|}
\hline Malignant diseases, n (\%) & $49(56.3 \%)$ \\
\hline Lung cancer, n (\%) & $13(14.9 \%)$ \\
\hline Hepatobiliary cancer, n (\%) & $12(13.8 \%)$ \\
\hline Gastrointestinal cancer, n (\%) & $8(9.2 \%)$ \\
\hline Urological cancer, n (\%) & $7(8.0 \%)$ \\
\hline Gynecological cancer, n (\%) & $3(3.4 \%)$ \\
\hline Head and neck cancer, n (\%) & $2(2.3 \%)$ \\
\hline Breast cancer, n (\%) & $2(2.3 \%)$ \\
\hline Hematological malignancies, n (\%) & $2(2.3 \%)$ \\
\hline Benign diseases, n (\%) & $38(43.7 \%)$ \\
\hline Pneumonia, n (\%) & I5 (I7.2\%) \\
\hline Cardiovascular disease, $\mathrm{n}(\%)$ & $10(11.5 \%)$ \\
\hline Sudden death/unknown death, $\mathrm{n}(\%)$ & $8(9.2 \%)$ \\
\hline Liver cirrhosis, n (\%) & $2(2.3 \%)$ \\
\hline Interstitial pneumonia, n (\%) & I (I.I\%) \\
\hline Asthma attack, n (\%) & I (I.I\%) \\
\hline Infectious endocarditis, n (\%) & I (I.I\%) \\
\hline Total, n (\%) & $87(100 \%)$ \\
\hline
\end{tabular}

moderate airflow limitation ( $\mathrm{FEV}_{1} \%$ predicted $\geq 50 \%$ ), the number of patients with malignant disease was high. In the group with severe airflow limitation $\left(\mathrm{FEV}_{1} \%\right.$ predicted $<50 \%$ ), three patients had malignant disease; the percentage of malignant disease among all causes of death was $33.3 \%$ (Figure 1B).

\section{Prevalence of malignancy in patients with asthma and ACOS}

In this study, we also surveyed all malignancies during the period from January 2000 to March 2012. Among

Table 4 Causes of death of 87 patients classified by asthma or ACOS diagnosis

\begin{tabular}{|c|c|c|}
\hline & Asthma & Acos \\
\hline Malignant diseases, $\mathrm{n}(\%)$ & $31(57.4 \%)$ & $18(54.5 \%)$ \\
\hline Lung cancer, n (\%) & $10(18.6 \%)$ & $3(9.1 \%)$ \\
\hline Hepatobiliary cancer, n (\%) & $8(\mid 4.8 \%)$ & $4(12.1 \%)$ \\
\hline Gastrointestinal cancer, n (\%) & $3(5.6 \%)$ & $5(15.2 \%)$ \\
\hline Urological cancer, n (\%) & $2(3.7 \%)$ & $5(15.2 \%)$ \\
\hline Gynecological cancer, n (\%) & $3(5.6 \%)$ & $0(0.0 \%)$ \\
\hline Head and neck cancer, n (\%) & $2(3.7 \%)$ & $0(0.0 \%)$ \\
\hline Breast cancer, n (\%) & $2(3.7 \%)$ & $0(0.0 \%)$ \\
\hline Hematological malignancies, n (\%) & I (I.9\%) & I (3.0\%) \\
\hline Benign diseases, $\mathrm{n}(\%)$ & $23(42.6 \%)$ & $15(45.5 \%)$ \\
\hline Pneumonia, n (\%) & $7(13.0 \%)$ & $8(24.2 \%)$ \\
\hline Cardiovascular disease, n (\%) & $5(9.3 \%)$ & $5(15.2 \%)$ \\
\hline Sudden death/unknown death, $\mathrm{n}(\%)$ & $6(11.1 \%)$ & $2(6.1 \%)$ \\
\hline Liver cirrhosis, n (\%) & $2(3.7 \%)$ & $0(0.0 \%)$ \\
\hline Interstitial pneumonia, n (\%) & I (I.9\%) & $0(0.0 \%)$ \\
\hline Asthma attack, n (\%) & I (I.9\%) & $0(0.0 \%)$ \\
\hline Infectious endocarditis, n (\%) & I (I.9\%) & $0(0.0 \%)$ \\
\hline Total, n (\%) & $54(100 \%)$ & $33(100 \%)$ \\
\hline
\end{tabular}

Abbreviations: ACOS, asthma-COPD overlap syndrome; COPD, chronic obstructive pulmonary disease.
149 patients with malignancy, 92 and 57 had asthma alone and ACOS, respectively. Lung and mediastinal malignancies were most frequently observed in asthma patients and second most frequently observed in ACOS patients. In ACOS patients, gastrointestinal cancer was the most commonly observed malignant disease and urological cancer was the third; in asthma patients, gastrointestinal cancer was the second and urological cancer was the third. Therefore, these three malignancies were most frequently observed in patients with asthma and ACOS (Table 5).

\section{Histology of lung cancer in patients with asthma and ACOS}

Since lung cancer was frequently observed in this study, the histology of lung cancer was surveyed (Table 6). In the asthma group, the proportion of adenocarcinoma was high (78.3\%). On the other hand, the proportion of squamous cell carcinoma was slightly higher in the ACOS group (46.7\%), while proportion of adenocarcinoma was $40.0 \%$.

\section{Discussion}

In this study, we surveyed causes of death in patients with asthma and ACOS. The increased mortality in ACOS may be caused by older age and more smoking consumption compared with asthma. Among patients with asthma, malignant disease was the leading cause of death, pneumonia was the second highest, and cardiovascular disease was the third highest. When patients were divided into asthma and ACOS groups, similar results were obtained. In the general Japanese population, malignant disease is the leading cause of death, cardiovascular disease is the second, and pneumonia is the third. ${ }^{5}$

There are several reports about causes of death in patients with asthma. ${ }^{22-24}$ Soto-Campos et al reported that the most common causes of death were cardiovascular disease, malignancy, and infection in asthmatic patients. ${ }^{11}$ In elderly asthmatic patients, cardiovascular diseases, non-neoplastic lung diseases, and neoplastic diseases were the most common causes of death. ${ }^{23,25}$ Causes of death in COPD patients have been investigated in several studies, and the main causes were respiratory failure, cardiovascular disease, and lung cancer. ${ }^{14}$ In this study, lung cancer was the fifth leading cause of death, while the most frequent cause of death in ACOS patients was pneumonia. We did not find any death from respiratory insufficiency. Rodriguez-Roisin et al reported that the degree of airflow limitation was related to the cause of death in COPD patients. As a cause of death, the lower the $\mathrm{FEV}_{1}$, the more frequent is respiratory failure. However, in patients with mild airflow limitation, lung cancer was the most frequent 
A

$80 \%$ predicted $\leq \mathrm{FEV}_{1}$

$50 \% \leq \mathrm{FEV}_{1}<80 \%$ predicted

$50 \%$ predicted $>\mathrm{FEV}_{1}$

$80 \%$ predicted $\leq \mathrm{FEV}_{1}$

$50 \% \leq \mathrm{FEV}_{1}<80 \%$ predicted

$50 \%$ predicted $>$ FEV $_{1}$

B
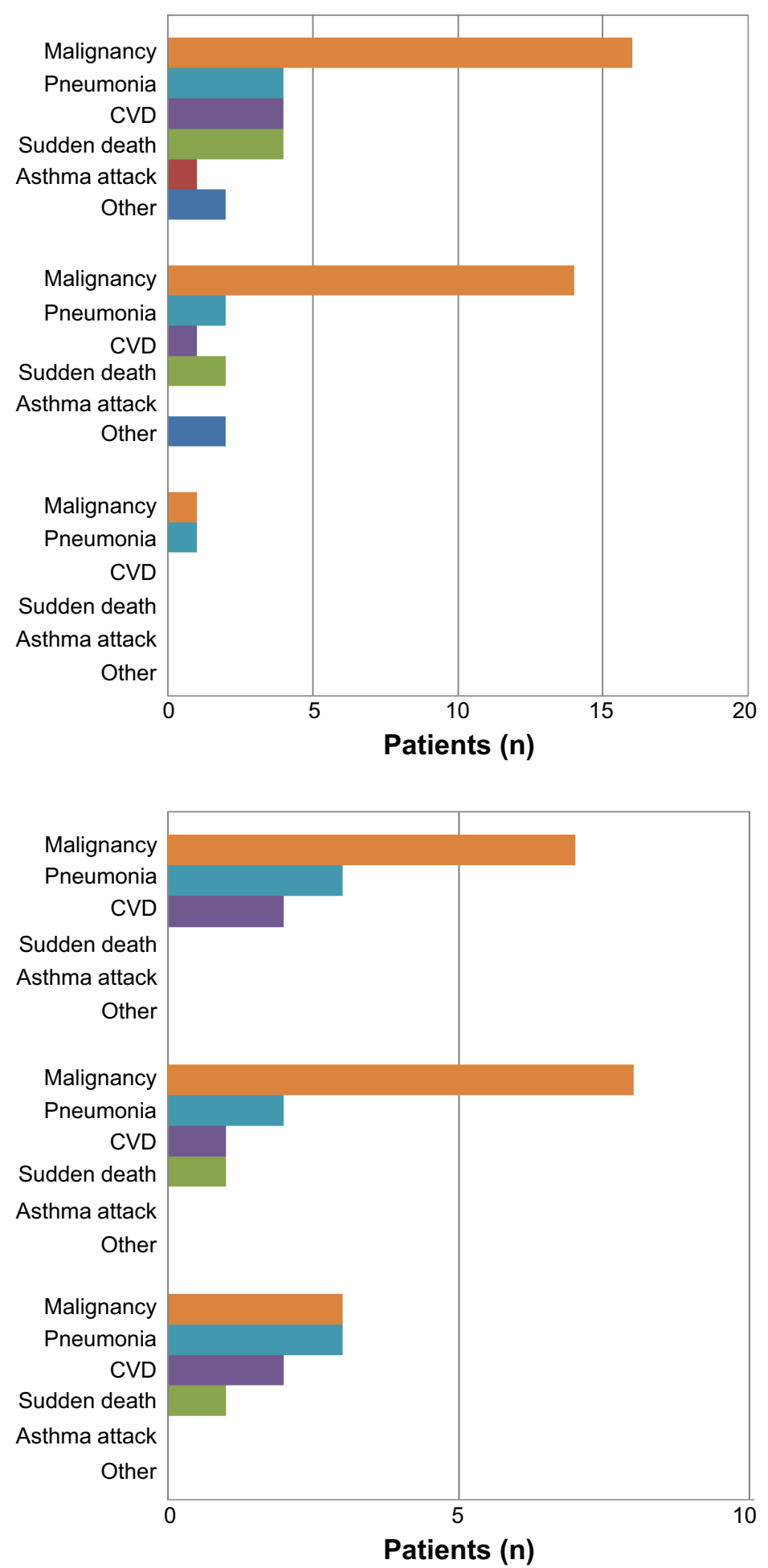

Figure I (A) Causes of death in 54 asthma patients classified by degree of airflow limitation. (B) Causes of death in 33 ACOS patients classified by degree of airflow limitation. Abbreviations: ACOS, asthma-COPD overlap syndrome; COPD, chronic obstructive pulmonary disease; CVD, cardiovascular disease; FEV in one second.

cause of death. ${ }^{26}$ In our study, causes of death were classified according to the degree of airflow limitation. In patients with asthma or ACOS with mild or moderate airflow limitation, malignant disease was the most frequent cause of death. In patients with asthma or ACOS with severe or very severe airflow limitation, the same numbers of patients died from infectious and malignant diseases. Therefore, malignant disease, including lung cancer, was the most frequent cause 
Table 5 Prevalence of malignancy in patients with asthma and ACOS

\begin{tabular}{|c|c|c|}
\hline & Asthma & Acos \\
\hline & $(n=474)$ & $(n=176)$ \\
\hline Malignant diseases, n (\%) & 92 (19.4\%) & $57(29.5 \%)$ \\
\hline Lung and mediastinal malignancy, n (\%) & 25 (27.2\%) & I 5 (26.3\%) \\
\hline Hepatobiliary cancer, n (\%) & II (I2.0\%) & $5(8.8 \%)$ \\
\hline Gastrointestinal cancer, n (\%) & $16(17.4 \%)$ & $22(38.6 \%)$ \\
\hline Urological cancer, n (\%) & $13(14.1 \%)$ & $15(26.3 \%)$ \\
\hline Gynecological cancer, n (\%) & $12(13.0 \%)$ & $0(0.0 \%)$ \\
\hline Head and neck cancer, n (\%) & $7(7.6 \%)$ & $3(5.3 \%)$ \\
\hline Breast cancer, n (\%) & $12(13.0 \%)$ & $0(0.0 \%)$ \\
\hline Hematological malignancies, n (\%) & $3(3.3 \%)$ & $3(5.3 \%)$ \\
\hline Femoral liposarcoma, n (\%) & $0(0.0 \%)$ & $\mathrm{I}(\mathrm{I} .8 \%)$ \\
\hline Unknown primary cancer, n (\%) & $0(0.0 \%)$ & $\mathrm{I}(\mathrm{I} .8 \%)$ \\
\hline
\end{tabular}

Note: Double cancers are included.

Abbreviations: ACOS, asthma-COPD overlap syndrome; COPD, chronic obstructive pulmonary disease.

of death in patients with milder airflow limitation, although the present study population was small.

In this study, we observed 149 patients with malignant disease, including 38 with lung cancer; the most frequent histological type was adenocarcinoma in asthma patients and squamous cell carcinoma in ACOS patients. Asthma has been hypothesized to be associated with an increased or decreased risk of lung cancer; however, a pooled analysis showed that the relative risk of lung cancer associated with asthma was 1.28 , with large heterogeneity. ${ }^{27} \mathrm{~A}$ recent large pooled study showed that asthma had an inverse association with lung cancer. ${ }^{28}$ Further, a history of atopic disease has been reported to be associated with a reduced risk of cancer. ${ }^{29}$ Immunoglobulin E levels were higher in patients with malignancy than in those without malignancy (399.0 IU/L and 567.4 IU/L, respectively). Although the protective effects of asthma and atopic disease against cancer are not clear, it is interesting that immunoglobulin E levels were higher in patients with asthma and malignant disease. Further study is warranted to clarify the relationship between atopy and lung cancer in patients with asthma and ACOS.

Table 6 Lung cancer histology in patients with asthma and ACOS

\begin{tabular}{lll}
\hline & Asthma & ACOS \\
\hline Lung cancer, $\mathrm{n}$ & 23 & 15 \\
Adenocarcinoma, $\mathrm{n}(\%)$ & $18(78.3 \%)$ & $6(40.0 \%)$ \\
Squamous cell carcinoma, $\mathrm{n}(\%)$ & $3(13.0 \%)$ & $7(46.7 \%)$ \\
Small cell carcinoma, $\mathrm{n}(\%)$ & $2(8.7 \%)$ & $\mathrm{I}(6.7 \%)$ \\
Unknown, $\mathrm{n}(\%)$ & $0(0.0 \%)$ & $\mathrm{I}(6.7 \%)$ \\
\hline
\end{tabular}

Abbreviations: ACOS, asthma-COPD overlap syndrome; COPD, chronic obstructive pulmonary disease.
Lung cancer was the major comorbidity and cause of death in COPD patients, ${ }^{14,30}$ and emphysema was an independent risk factor for lung cancer apart from smoking history and degree of airflow limitation. ${ }^{15,31,32}$ Recent studies have shown that COPD, emphysema, and chronic bronchitis were associated with an increased risk of lung cancer, while asthma was associated with a decreased risk. ${ }^{27,28}$ In this study, we found that the prevalence of lung cancer was similar between patients with asthma and those with ACOS.

We diagnosed ACOS referring to the ACOS statement. ${ }^{19}$ We enrolled patients with persistent airflow limitation and a smoking history of at least 10 pack-years. The prevalence of COPD increased with increasing smoking history. ${ }^{33}$ However, some COPD patients have no smoking history, ${ }^{34}$ and asthma itself is a risk factor for COPD. ${ }^{35,36}$ However, it is difficult to distinguish patients with asthma who have airway remodeling and persistent airflow limitation from patients with ACOS among those with a light or no smoking history and without emphysema or low attenuation areas observed on chest computed tomography. Therefore, we set the cutoff value for smoking history to 10 pack-years according to previous clinical studies on COPD. ${ }^{37,38}$

In this study, the prevalence of ACOS in all asthma patients was $27.1 \%$. When the analysis was restricted to patients over 65 years of age, the prevalence of ACOS was $35.3 \%$ (133 ACOS patients among 377 patients with asthma). Soriano et al reported that the rate of COPD overlap increased with age, and more than half of patients with asthma aged 80 years or older presented with COPD overlap. ${ }^{39}$ de Marco et al reported on the prevalence of asthma and COPD coexisting in the young, middle-aged, and elderly general population. ${ }^{40}$ They found that the frequency of ACOS was $1.6 \%, 2.1 \%$, and $4.5 \%$ in the groups aged $20-44,45-64$, and 65-84 years, respectively; while the frequency of asthma was $8.2 \%, 4.9 \%$, and $2.9 \%$ in the groups aged $20-44,45-64$, and 65-84 years, respectively. Although they did not mention the prevalence, about $23 \%$ of patients were estimated to have ACOS. ${ }^{40}$ Therefore, the prevalence of ACOS in patients with asthma in this study was consistent with the findings of previous studies.

Eight patients died suddenly; two patients died in a bathroom and two died after drinking alcohol. All these patients were seen by their family or friends without any symptoms of asthma within 12 hours of death. Although we could not completely exclude an asthma attack as the cause of death, they probably died of cardiovascular events, and we defined their deaths as sudden death/unknown death. 
A limitation of this study was that we could not survey all patients with asthma and ACOS. Some asthmatic patients with no or few respiratory symptoms stopped visiting our hospital or changed to another hospital when their respiratory symptoms disappeared. A further limitation of this study was that the sample size was too small to compare causes of deaths between asthma and ACOS. The study was also retrospective in nature, and did not include patients with COPD alone. Prospective studies are necessary to study mortality risk factors in asthma, COPD, and ACOS patients in larger cohorts.

In conclusion, the most frequent cause of death in patients with asthma and ACOS was malignant disease. It is necessary to control both asthma and comorbidities in patients with asthma, and especially in those with ACOS.

\section{Disclosure}

The authors report no conflicts of interest in this work.

\section{References}

1. Asher MI, Montefort S, Bjorksten B, et al. Worldwide time trends in the prevalence of symptoms of asthma, allergic rhinoconjunctivitis, and eczema in childhood: ISAAC Phases One and Three repeat multicountry cross-sectional surveys. Lancet. 2006;368(9537):733-743.

2. Shimizu K, Konno S, Kimura H, et al. [Prevalence of adult asthma and allergic rhinitis in Kamishihoro, Hokkaido-trends from 2006 through 2011]. Arerugi. 2014;63(7):928-937. Japanese.

3. Ohta $\mathrm{K}$, Ichinose M, Nagase $\mathrm{H}$, et al. Japanese guideline for adult asthma 2014. Allergology. 2014;63(3):293-333.

4. Suissa S, Ernst P, Benayoun S, Baltzan M, Cai B. Low-dose inhaled corticosteroids and the prevention of death from asthma. N Engl J Med. 2000;343(5):332-336.

5. Statistics and Information Department, Minister's Secretariat, Ministry of Health and Welfare, Japan. Vital Statistics Japan 3. Tokyo, Japan: Health and Welfare Statistics Association; 2012-2013.

6. Ito Y, Tamakoshi A, Wakai K, Takagi K, Yamaki K, Ohno Y. Trends in asthma mortality in Japan. $J$ Asthma. 2002;39(7):633-639.

7. Tsai CL, Lee WY, Hanania NA, Camargo CA Jr. Age-related differences in clinical outcomes for acute asthma in the United States, 2006-2008. J Allergy Clin Immunol. 2012;129(5):1252-1258. e1251.

8. Gibson PG, McDonald VM, Marks GB. Asthma in older adults. Lancet. 2010;376(9743):803-813.

9. Iwanaga T, Tohda Y. [Bronchial asthma: progress in diagnosis and treatments. Topics: I. Basic knowledge; 3. Asthma in the elderly]. Nihon Naika Gakkai Zasshi. 2013;102(6):1343-1351. Japanese.

10. Lozano R, Naghavi M, Foreman K, et al. Global and regional mortality from 235 causes of death for 20 age groups in 1990 and 2010: a systematic analysis for the Global Burden of Disease Study 2010 Lancet. 2012;380(9859):2095-2128.

11. Soto-Campos JG, Plaza V, Soriano JB, et al. Causes of death in asthma, COPD and non-respiratory hospitalized patients: a multicentric study. BMC Pulm Med. 2013;13:73.

12. Zielinski J, MacNee W, Wedzicha J, et al. Causes of death in patients with COPD and chronic respiratory failure. Monaldi Arch Chest Dis. 1997;52(1):43-47.

13. Garcia-Aymerich J, Farrero E, Felez MA, Izquierdo J, Marrades RM, Anto JM. Risk factors of readmission to hospital for a COPD exacerbation: a prospective study. Thorax. 2003;58(2):100-105.

14. Sin DD, Anthonisen NR, Soriano JB, Agusti AG. Mortality in COPD: role of comorbidities. Eur Respir J. 2006;28(6):1245-1257.
15. Wilson DO, Weissfeld JL, Balkan A, et al. Association of radiographic emphysema and airflow obstruction with lung cancer. Am J Respir Crit Care Med. 2008;178(7):738-744.

16. Gibson PG, Simpson JL. The overlap syndrome of asthma and COPD: what are its features and how important is it? Thorax. 2009;64(8): 728-735.

17. Menezes AM, Montes de Oca M, Perez-Padilla R, et al. Increased risk of exacerbation and hospitalization in subjects with an overlap phenotype: COPD-asthma. Chest. 2014;145(2):297-304.

18. Pleasants RA, Ohar JA, Croft JB, et al. Chronic obstructive pulmonary disease and asthma-patient characteristics and health impairment. COPD. 2014;11(3):256-266.

19. Diagnosis of Diseases of Chronic Airflow Limitation: Asthma COPD and Asthma-COPD Overlap Syndrome (ACOS). Based on the Global Strategy for Asthma Management and Prevention and the Global Strategy for the Diagnosis, Management and Prevention of Chronic Obstructive Pulmonary Disease, 2014. Available from: http://www. ginasthma.org/local/uploads/files/AsthmaCOPDOverlap.pdf. Accessed February 3, 2015.

20. Standards for the diagnosis and care of patients with chronic obstructive pulmonary disease (COPD) and asthma. This official statement of the American Thoracic Society was adopted by the ATS Board of Directors, November 1986. Am Rev Respir Dis. 1987;136(1):225-244.

21. Global Initiative for Chronic Obstructive Pulmonary Disease (GOLD). Global Strategy for Diagnosis, Management and Prevention of COPD. 2014. Available from: http://www.goldcopd.org/guidelines-global-strategyfor-diagnosis-management.html. Accessed February 3, 2015.

22. Reed CE. The natural history of asthma. J Allergy Clin Immunol. 2006; 118(3):543-548.

23. Bauer BA, Reed CE, Yunginger JW, Wollan PC, Silverstein MD. Incidence and outcomes of asthma in the elderly. A population-based study in Rochester, Minnesota. Chest. 1997;111(2):303-310.

24. Silverstein MD, Reed CE, O'Connell EJ, Melton LJ 3rd, O'Fallon WM, Yunginger JW. Long-term survival of a cohort of community residents with asthma. N Engl J Med. 1994;331(23):1537-1541.

25. Reed CE. Onset and outcome of asthma in older adults. A clinician's perspective. Clin Rev Allergy Immunol. 2002;22(1):53-65.

26. Rodriguez-Roisin R, Soriano JB. Chronic obstructive pulmonary disease with lung cancer and/or cardiovascular disease. Proc Am Thorac Soc. 2008;5(8):842-847.

27. Rosenberger A, Bickeboller H, McCormack V, et al. Asthma and lung cancer risk: a systematic investigation by the International Lung Cancer Consortium. Carcinogenesis. 2012;33(3):587-597.

28. Denholm R, Schuz J, Straif K, et al. Is previous respiratory disease a risk factor for lung cancer? Am J Respir Crit Care Med. 2014;190(5): 549-559.

29. Wang H, Diepgen TL. Is atopy a protective or a risk factor for cancer? A review of epidemiological studies. Allergy. 2005;60(9):1098-1111.

30. Chatila WM, Thomashow BM, Minai OA, Criner GJ, Make BJ. Comorbidities in chronic obstructive pulmonary disease. Proc Am Thorac Soc. 2008;5(4):549-555.

31. de Torres JP, Bastarrika G, Wisnivesky JP, et al. Assessing the relationship between lung cancer risk and emphysema detected on low-dose CT of the chest. Chest. 2007;132(6):1932-1938.

32. Zulueta JJ, Wisnivesky JP, Henschke CI, et al. Emphysema scores predict death from COPD and lung cancer. Chest. 2012;141(5): 1216-1223.

33. Lundback B, Lindberg A, Lindstrom M, et al. Not 15 but $50 \%$ of smokers develop COPD? - Report from the Obstructive Lung Disease in Northern Sweden Studies. Respir Med. 2003;97(2):115-122.

34. Hagstad S, Ekerljung L, Lindberg A, Backman H, Ronmark E, Lundback B. COPD among non-smokers - report from the Obstructive Lung Disease in Northern Sweden (OLIN) studies. Respir Med. 2012; 106(7):980-988.

35. Tai A, Tran H, Roberts M, Clarke N, Wilson J, Robertson CF. The association between childhood asthma and adult chronic obstructive pulmonary disease. Thorax. 2014;69(9):805-810. 
36. Silva GE, Sherrill DL, Guerra S, Barbee RA. Asthma as a risk factor for COPD in a longitudinal study. Chest. 2004;126(1):59-65.

37. Decramer M, Celli B, Kesten S, Lystig T, Mehra S, Tashkin DP. Effect of tiotropium on outcomes in patients with moderate chronic obstructive pulmonary disease (UPLIFT): a prespecified subgroup analysis of a randomised controlled trial. Lancet. 2009;374(9696): $1171-1178$.

38. D'Urzo A, Ferguson GT, van Noord JA, et al. Efficacy and safety of once-daily NVA237 in patients with moderate-to-severe COPD: the GLOW1 trial. Respir Res. 2011;12:156.
39. Soriano JB, Davis KJ, Coleman B, Visick G, Mannino D, Pride NB. The proportional Venn diagram of obstructive lung disease: two approximations from the United States and the United Kingdom. Chest. 2003;124(2):474-481.

40. de Marco R, Pesce G, Marcon A, et al. The coexistence of asthma and chronic obstructive pulmonary disease (COPD): prevalence and risk factors in young, middle-aged and elderly people from the general population. PLoS One. 2013;8(5):e62985.

\section{Publish your work in this journal}

The International Journal of COPD is an international, peer-reviewed journal of therapeutics and pharmacology focusing on concise rapid reporting of clinical studies and reviews in COPD. Special focus is given to the pathophysiological processes underlying the disease, intervention programs, patient focused education, and self management protocols.

\section{Dovepress}

This journal is indexed on PubMed Central, MedLine and CAS. The manuscript management system is completely online and includes a very quick and fair peer-review system, which is all easy to use. Visit $\mathrm{http} / / / \mathrm{www}$.dovepress.com/testimonials.php to read real quotes from published authors. 